\title{
Analysis and Design of the equipment loan control system (SCPE) of laboratories of the ICT major of the UTVT
}

\section{Análisis y Diseño del sistema de control de préstamos de equipos (SCPE) de laboratorios de la carrera de TIC de la UTVT}

\author{
ORONA-LOPEZ, Miguel Angel ${ }^{* \dagger} \uparrow$, MAYA-PÉREZ, Petra Norma, ROSALES-AVILES, Pamela Elisa \\ and REYES-BALTAZAR, Nancy
}

\author{
Universidad Tecnológica del Valle de Toluca, Carretera del Departamento del D.F. km 7.5, Santa María Atarasquillo, Lerma, \\ México
}

ID $1^{\text {st }}$ Author: Miguel Angel, Orona-Lopez / ORC ID: 0000-0003-0075-1253, Researcher ID Thomson: S-8754-2018, CVU CONACYT ID: 678742

ID $1^{\text {st }}$ Coauthor: Petra Norma, Maya-Pérez / ORC ID: 0000-0001-5531-5358, Researcher ID Thomson: S-7924-2018, CVU CONACYT ID: 429523

ID $2^{\text {nd }}$ Coauthor: Pamela Elisa, Rosales-Aviles / ORC ID: 0000-0003-0025-2294, Researcher ID Thomson: T-1428-2018, CVU CONACYT ID: 458460

ID $3^{\text {rd }}$ Coauthor: Nancy, Reyes-Baltazar

DOI: $10.35429 / J M Q M .2019 .4 .3 .27 .31$

Received March 28, 2019; Accepted June 10, 2019

\begin{abstract}
The present work exposes the analysis and design of the Equipment Loan Control System (SCPE). We developed a system in its analysis and design phases of control of equipment inputs and outputs (loans), reducing time and showing reports to be able to make decisions about a subsequent acquisition of equipment or different administration. The functionality of the system is based on the procedure P-EDU-05 http://sgi.utvtol.org.mx/ mainly on the points: 8.2 (update of the equipment inventory) 8.4 (Delivery of laboratory hours) 8.5 (Verification of the laboratory schedule) 8.7 Registration of PTC/PA (Full Time Professor/Subject Professor) in a later version using a fingerprint reader. In this delivery, procedures, processes and calculations will be analyzed; as well as define interfaces. In point 8.7 , it will register compliance of the service at the end of the practice. It will also include a processing, calculating the compliance rates according to the procedure. The laboratory/equipment registration interface will reflect what is required in the R-EDU-20-General requirements for laboratory/workshop practices. Finally, the RAD (Rapid Application Development) methodology will be used to develop the system due to the use of fourth generation techniques to reuse existing programs.
\end{abstract}

System, Control, Loan, Schedules

\begin{abstract}
Resumen
El presente trabajo expone el análisis y el diseño del Sistema de control de préstamos de equipos (SCPE), donde se desarrolla un sistema en sus fases de análisis y diseño de control de salidas y entradas de equipo (préstamos), disminuyendo tiempo y mostrando reportes para poder tomar decisiones acerca de una siguiente adquisición de equipo o diferente administración. La funcionalidad del sistema está basado en el procedimiento PEDU-05 http://sgi.utvtol.org.mx/ principalmente en los puntos: 8.2 (actualización del inventario de equipo) 8.4 (Entrega de horarios de laboratorio) 8.5 (Verificación del horario de laboratorio) 8.7 Registro de PTC/PA(Profesor de Tiempo Completo/Profesor de Asignatura) en una versión posterior por medio de lector de huella digital. En ésta entrega se analizarán procedimientos, procesos y cálculos; así como definir interfaces. En el punto 8.7 registrará conformidad del servicio al finalizar la práctica. También incluirá un procesamiento calculando los índices de conformidad de acuerdo al procedimiento. La interfaz de registro de laboratorio/equipo, reflejará lo requerido en el formato R-EDU-20-Requerimientos generales para prácticas de laboratorio/taller. Por último, se utilizará la metodología RAD (Desarrollo Rápido de Aplicaciones) para desarrollar el sistema debido a la utilización de técnicas de cuarta generación para reutilizar programas ya existentes.
\end{abstract}

Sistema, Control, Préstamo, Horarios

Citation: ORONA-LOPEZ, Miguel Angel, MAYA-PÉREZ, Petra Norma, ROSALES-AVILES, Pamela Elisa and REYESBALTAZAR, Nancy. Analysis and Design of the equipment loan control system (SCPE) of laboratories of the ICT major of the UTVT. Journal-Mathematical and Quantitative Methods. 2019. 3-4: 27-31

\footnotetext{
* Correspondence to Author (email: miguel.orona @utvtol.edu.mx)

$\dagger$ Researcher contributing first author
} 


\section{Introduction}

The development of specialized software favors the optimization and performance of resources; therefore, the SCPE will promote a correct and unprecedented decision-making tool that will allow the correct administration of both the laboratories of the ICT major at UTVT and the equipment. When developing the software, we used the RAD (rapid application development) methodology because there is a shortage of personnel for its development. We used previously generated software, which mainly saved time in development and favored the reuse of code for a later version.

\section{Justification}

Currently, records are kept manually, so the waste of paper and the lack of control through a system implies a loss of time and resources; therefore, we present a solution.

\section{Problem}

The actual process is slow, and inconsistencies in capturing and reporting are typical as an Excel is captured at the end of a quarter, which is intended to be automated.

\section{Hypothesis}

Loan management of laboratories and equipment helps to solve the problem of availability since sometimes the use of material or laboratories is required without prior notice; which takes time for the teacher and/or students, where the system will help generate a "live" use report where availability will be consulted, which will allow teachers and students to take advantage of their time by not moving to the laboratory due to lack of availability. In the same way, there will be a report on the use of the material and/or laboratories where the system will allow us to know if the loan is at the limit, where demand exceeds supply, and it is necessary to acquire new units for the loan.

\section{Development of Sections and Subsections of the Article with subsequent numbering}

\section{Theoretical Framework}

Somerville describes software as follows:
Many people associate the term software with computer programs. However, I prefer a broader definition in which software is not just programs, but all the associated documents and data settings that are needed to make these programs operate correctly.

(Somerville, 2005, p. 5).

The way to save data will be similar to that of Silberschatz:

"The collection of data, usually referred to as the database, contains information relevant to an enterprise. The primary goal of a DBMS is to provide a way to store and retrieve database information that is both convenient and efficient. (Silberschatz, 2011, p. 1)

The general tools have already been defined as indicated by Somerville:

"The system requirement definitions specify what the system should do (its functions) and its essential and desirable properties." (Somerville, 2005, p. 24).

\section{Collection of requirements:}

\section{Functional requirements}

- $\quad$ Registration, deletion, modification and consultation of:

- $\quad$ Equipment.

- Users: teachers and students.

- General requirements (self-generated format).

- $\quad$ Generation of reports:

- Utilization and loan index.

- $\quad$ Equipment availability.

\section{Non-functional requirements}

- $\quad$ Local server with a $2.8 \mathrm{Ghz}$ single core processor.

- Windows or Linux operating system.

- $\quad$ Apache server.

- $\quad$ PHP 5 or later.

- $\quad$ Mysql server.

- $\quad 50 \mathrm{~Gb}$ of available storage.

- 2 Personal computers available for teacher or student registration. 
The software will be designed for a client-server architecture in cutting edge technologies such as HTML (HyperText Markup Language) in its version 5 and CSS (Cascade Style Sheet) in its version 3; together with PHP (Hypertext Pre-Processor) in its version 5; and will be implemented under a MVC (Model View Controller) structure. Next, the relational model of the database is developed in its basic form, since it allows the creation of entities (tables) and "sub-entities" (attributes) that acquire form to be able to make later diagrams, such as the general UML of the project:

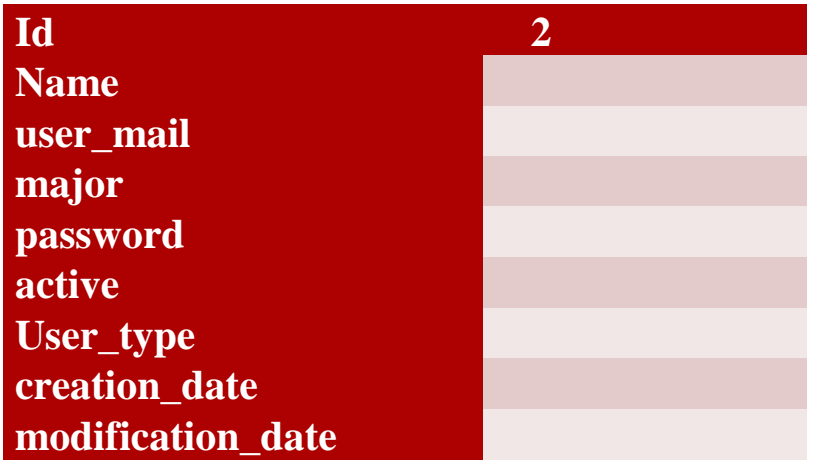

Table 1 BD Users

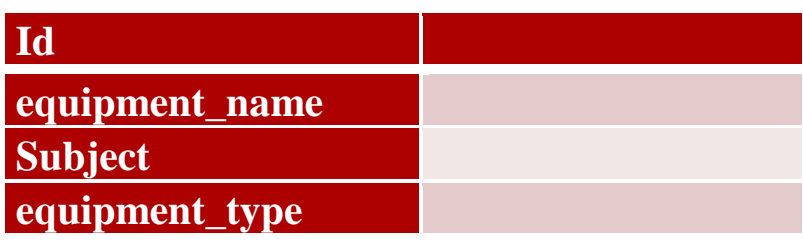

Table 2 BD subjects

\begin{tabular}{|l|l|}
\hline id & Schedule \\
\hline 1 & $7-7: 50$ \\
\hline 2 & $7: 50-8: 40$ \\
\hline 3 & $8: 40-9: 30$ \\
\hline 4 & $9: 30-10: 20$ \\
\hline 5 & $10: 20-12: 00$ \\
\hline 6 & $12: 00-12: 5$ \\
\hline 7 & $12: 50-: 13: 40$ \\
\hline 8 & $13: 40-14: 30$ \\
\hline 9 & $14: 30-: 15: 20$ \\
\hline 10 & $15: 20-16: 10$ \\
\hline 11 & $16: 10-: 17: 00$ \\
\hline 12 & $17: 00-: 17: 50$ \\
\hline 13 & $17: 50-18: 40$ \\
\hline 14 & $18: 40-19: 30$ \\
\hline 15 & $19: 30-: 20: 20$ \\
\hline 16 & $20: 20-21: 00$ \\
\hline
\end{tabular}

Table 3 BD Schedule

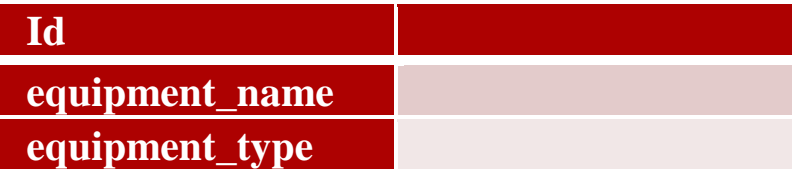

Table 4 BD equipments

\begin{tabular}{|l|l|}
\hline Id & \\
\hline equipment_name \\
\hline subject \\
\hline equipment_type \\
\hline
\end{tabular}

Table 5 BD users-subjects-schedule

\begin{tabular}{|l|l|}
\hline Id & \\
\hline practice & \\
\hline address & \\
\hline Group & \\
\hline date & \\
\hline subject & \\
\hline laboratory & \\
\hline schedule & \\
\hline target & \\
\hline software & \\
\hline fingerprint_id & \\
\hline
\end{tabular}

\section{Table 6 BD General requirements}

A CRUD will be allowed for all the tables (additions, deletions, modifications and consultations); although for all the cases the deletions will be logical; since a record must exist "forever" due to the fact that it will be possible to consult the historical from the beginning for a later revision or data analysis.

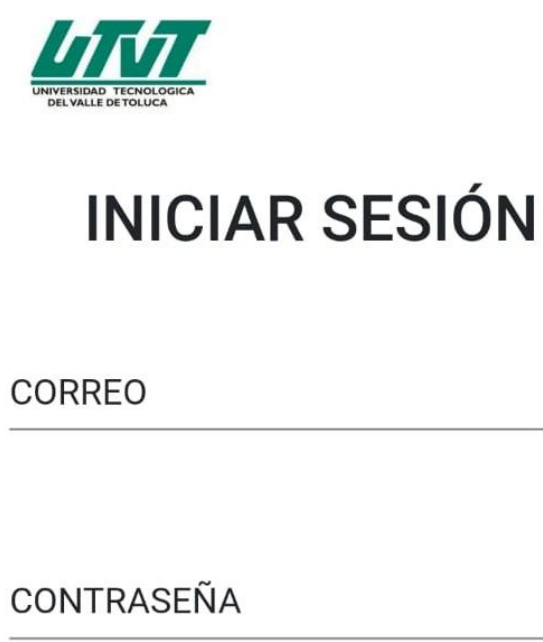

\section{INICIAR SESIÓN}

Figure 1 Logging in

ORONA-LOPEZ, Miguel Angel, MAYA-PÉREZ, Petra Norma, ROSALES-AVILES, Pamela Elisa and REYES-BALTAZAR, Nancy. Analysis and Design of the equipment loan control system (SCPE) of laboratories of the ICT major of the UTVT. Journal-Mathematical and Quantitative Methods. 2019 


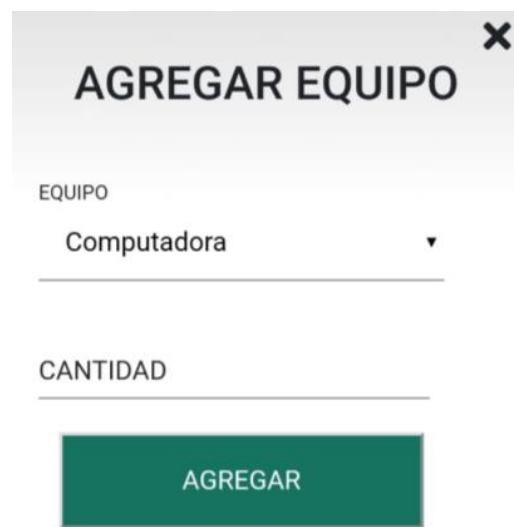

Figure 2 Adding equipment

\section{Loan Process}

The loan requested by default is that of laboratories, so the system will be prepared to quickly request a laboratory semi-automatically depending on the schedule in which the laboratory is requested, for example: The user $\operatorname{logs}$ in to the system at 10:20, and if the user has the subject of Programming Methodology in laboratory 3 , the system will display that subject, with that schedule by default and in the same laboratory 3 that is already pre-filled by the system.

\section{Characteristics of the SCPE}

Intelligent and agile: The system will display preloaded data of users, subjects, laboratory, schedules, equipment and acceptance or rejection.

Controls the availability (Throws available units)

Prediction tool (Determines if a change or purchase of equipment is needed to make it available).

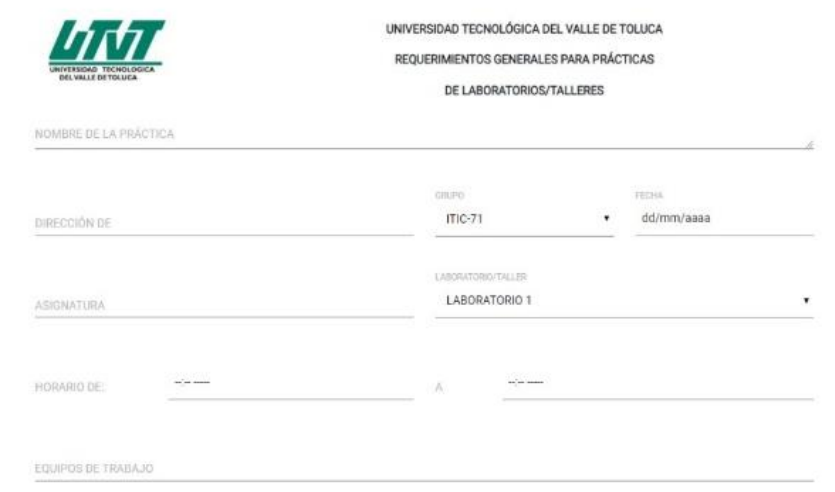

Figure 3 Laboratory/equipment loan

\section{Reports}

The reports that the system will throw will be:

$$
\begin{aligned}
& \text { Report of laboratory use per quarter at } \\
& \text { the time of consultation (in percentage) } \\
& \text { - } \quad \begin{array}{l}
\text { Material/Equipment use report (to know } \\
\text { if they need to buy more material) }
\end{array} \\
& \text { - } \quad \text { Consult real-time laboratory use } \\
& \text { - } \quad \text { Material/Equipment Loan Consultation }
\end{aligned}
$$

\section{General UML diagram of the SCPE}

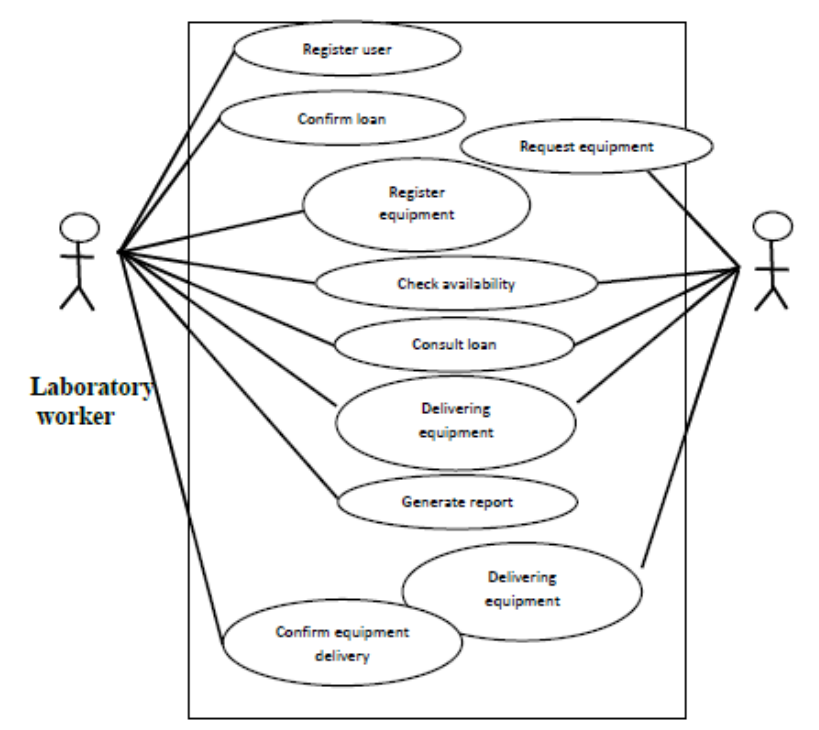

Figure 4 Diagrama UML General del SCPE

\section{Rapid Application Development (RAD) Methodology}

This methodology promotes the reuse of existing code or software. And what will be done in this work is:

\section{- $\quad$ Requirements planning

$$
\text { - Design }
$$

\section{Acknowledgement}

I am grateful for the funding from the Universidad Tecnológica de Toluca that made the publication of this article possible.

\section{Conclusions}

The use of Object Oriented allows to obtain a reusable code and with the RAD methodology it will be possible to remunerate the time used in the development. 
- The use of a unique key to use the equipment manages the traffic like a traffic light.

- $\quad$ SCPE will generate reports that will help solve "riddles" such as the requirement to purchase new equipment.

- The Model-View-Controller paradigm used in the SCPE system allows the "modularization" of the problems allowing to easily find the code divided by View (what is seen), Model (the processes) and Controller (the redirections); and thus within the code to section properly.

- $\quad$ The use of a fingerprint reader could cause a remarkable improvement in the loan process and avoid inconsistencies.

\section{References}

Minera, F. J. (2011). PHP avanzado. Lomas de Zamora: Fox Andina.

Silberschatz, A. (2011). Database System Concepts. New York: McGraw-Hill.

Somerville, I. (2005). Ingeniería del Software. Madrid: Pearson Education, S.A.

Sommerville, I. (2006). Fundamentos de Bases de Datos. Madrid. 